\title{
International Journal of Business Management and Economic Review
}

Vol. 2, No. 04; 2019

ISSN: 2581-4664

\section{EXPORTS AND ECONOMIC GROWTH IN TANZANIA: 1970-2017}

\author{
Ali A. L. Kilindo \\ $\mathrm{PhD}$, Senior Lecturer, Department of Economics, College of Social Sciences, University of Dar es Salaam, \\ Tanzania
}

http://doi.org/10.35409/IJBMER.2019.2402

\begin{abstract}
The study investigates the role of Exports in Economic Growth in Tanzania by testing The Export-Led Growth Hypothesis (ELGH). To obtain robust non-spurious regression results Dickey- Fuller (D-F) and Phillips-Peron (PP) Unit Root tests are performed. Further, Johansen Cointegration tests are employed to investigate long-run relationship between export, imports and economic growth. The Johansen test suggests a long run relationship between exports in general and manufactured exports in particular and economic growth. In addition, the ECM model results further support a long-run relationship between exports and economic growth in Tanzania during the period of study in support of the ELGH.
\end{abstract}

Keyword: Tanzania, Export-Led Growth, , Economic Growth.

\section{INTRODUCTION}

It is generally agreed that apart from increasing the amounts of labour and capital within an economy, the overall growth of the economy can be determined by expanding exports. This is the main argument of the export-led growth hypothesis (ELGH) which believes that exports can be an engine of growth.

The link between exports and growth emanates from the possible externalities that the domestic economy gets while participating in world markets. Examples of externalities include reallocation of existing resources and numerous training and productivity effects. It is shown in Pavcnik, (2002) that there is highly consistent and largely tested evidence that firms in more open sectors tend to be more productive and experience productivity growth. Monna-Haddad and Shepherd, (2011 a, b) show that at the policy level also, there is continuing consensus on the potential of outward-orientation to help promote economic growth and raise living standards and further document that no country in the past 50 years has sustained high levels of growth and increased per capita incomes significantly without greatly expanding its imports and exports.

Substantial theoretical and empirical proof exists identifying the mechanisms through which export expansion influences economic growth in developing countries. There have however been divergent lines of research, methodologies, time periods and countries covered.

Econometric techniques have mostly been used based on bivariate functions and in most cases stationarity tests have not been undertaken and thus the possibilities of spurious regressions have not been avoided. 


\section{International Journal of Business Management and Economic Review}

Vol. 2, No. 04; 2019

ISSN: 2581-4664

This study examines the ELGH for the case of Tanzania. Similar studies have been carried out in Tanzania in the past. This study can be distinguished from former studies in Tanzania in four aspects. First is that we cover a longer time, four and a half decades, 1970 to 2015, and in view of the policy changes that may have influenced the relationship among the variables investigated may have changed. Secondly, we further aggregate the export variable as opposed to disaggregating exports in goods and services as in Mohamed et.al, (2012) and confining to manufactured exports as in Kahyarara (2013) on agricultural exports as in Rwakalaza (2015). Thirdly the study goes beyond the traditional short-term effects and uses modern time series analysis to examine empirically the long-run relationship and proceeds to test for co-integration. Fourthly, up to now no attempt has been made to examine the aggregate effects of exports on Tanzania's economic growth. This study uses a country case study approach focusing on Tanzania to investigate whether a long run relationship exists between exports and economic growth which traditionally is equivalent to testing the Export-Led Growth (ELG) Hypothesis. In the final analysis the study will come up with a quantified measure of the importance of exports in the economic performance of Tanzania during the past four and a half decades.

\section{A Brief Background on economic and export- import performance}

Table 1 provides average value of these variables over the sample period. It is seen that Tanzania's economic performance reflected by the growth of GDP is considered impressive in the last decade. During the period 1970-79 average GDP growth was 5.7 percent decline to 2.7 percent during the 1980s, considered as tough years for the Tanzanian economy. This was due to the global recession of the early 1980s and the adverse shocks in commodity prices. This was followed by an impressive 4.8 and 6.9 per cent growth in the 1990s and the period 2000-2010. - Growth performance of the economy plunged and as result average GDP growth was only percent.

Since 2000 Tanzanian has recorded moderate economic performance resulting in an average growth of GDP of 6.9 percent during 2000-2010. For the period 2011to 2015 average growth recorded 7.2 percent.

In the mid 1980s, Tanzania liberalized its trade and moved towards an export oriented development strategy. Trade liberalization resulted in an increase in export ratio from 5.9 percent to 9.4 for the period 1980-1988 to the period 89-90. The contribution of exports to economic growth also improved as indicated by an increase in the export-GDP ratio from an average of 11.6 and 19.9 percent between 2000 and 2010 and 2011 to 2015 as a result of more export oriented policies were put in place. One would expect the remarkable improvement in export performance during the 1990s to translate into an acceleration of growth and productivity through greater capacity utilization, increased labour productivity, improved allocation of scarce resources, increased external earnings and increased foreign investment as theory predicts.

Table 1: Performance of selected variables $(\%)$

\begin{tabular}{|l|l|l|l|l|l|}
\hline Variables & $\mathbf{1 9 7 0 - 7 9}$ & $\mathbf{1 9 8 0 - 8 9}$ & $\mathbf{1 9 9 0 - 9 9}$ & $\mathbf{2 0 0 0 - 1 0}$ & $\mathbf{2 0 1 1 - 1 6}$ \\
\hline $\mathrm{y}$ & 5.5 & 2.7 & 4.8 & 6.9 & 7.2 \\
\hline $\mathrm{x}$ & 16.5 & 5.9 & 9.4 & 11.6 & 19.9 \\
\hline $\mathrm{m}$ & 22.2 & 16.5 & 25.2 & 28.2 & 18.5 \\
\hline
\end{tabular}




\section{International Journal of Business Management and Economic Review}

Vol. 2, No. 04; 2019

ISSN: 2581-4664

Notes: $\mathrm{y}$ is growth in GDP, $\mathrm{x}$ and $\mathrm{m}$ are the export -GDP and import-GDP ratio respectively

\section{REVIEW OF LITERATURE}

Despite controversy on the real effects of exports, the debate on the theoretical link between trade and economic growth has existed for a long time. The relation between economic growth and trade was first brought by Adam Smith and David Ricardo. In their spirit, among many other factors foreign trade plays a crucial role in attaining economic growth. In their view, if each country specialized on producing the goods in which it had a comparative advantage and export these goods, it would achieve a higher welfare level compared with the pre-trade position.

Recently it is observed in Medina-Smith (2001a) that early supporters of the trade-growth link include Bagwati (1978) and Krueger (1978) who built on the ideas of Ricardo and John Stuart Mill. In later attempts to empirically show the importance of trade in attaining sustainable economic development models were developed. The studies focused on variables such as the degree of openness, real exchange rate, tariffs, terms of trade and export performance to suggest that open economies grow faster than closed economies.

Outward oriented policies have accounted impressive the rates of growth of Hong Kong, Taiwan, Singapore and Korea and other Southeast Asian countries (Medina -Smith, op.cit.; Kokko, 1997). Similar arguments for the case of Europe are given in Kokko (2006). On the other hand, poor economic performance has been recorded in countries that followed inward oriented policies, under the Import Substitution Strategy (ISS). Belassa (1980) suggests that most Latin American Countries showed lack of growth or even decline in income due to inward -looking policies.

Tanzania also experienced poor economic performance during the period of 1960s to mid 80s. As Kanaan, (2000) documents, in the late 60s Import Substitution industrialization was Tanzania's dominating development strategy with the main aim of promoting heavy industry and achieving self-sufficiency in food production. Five Year Development Plans targeted expansion of a capital intensive industrial sector and infrastructure. Large public enterprises were set. In the 70 s trade restriction was used as a key tool for achieving the country's development priorities. The main source of export earnings was export cash crops which were sold to marketing parastatals at prices well below world prices. Other restrictions were placed on non-traditional exports via export permits. On the other hand, imports were regulated through administrative allocation of foreign exchange and import licensing. The restrictive trade regime and cost-price distortions impaired on allocative efficiency and longer-term macroeconomic performance. As a result, during the late 70s and mid 80s Tanzania attained very slow growth.

After analyzing these developments, Kanaan, op. cit. suggests that the phasing out of trade restrictions in the mid 1980s has played a key role in the revival of the export sector and laid the foundation for sustainable growth.

The role of openness on economic performance drove scholars to advocate outward-oriented policies. This brought the birth of export-led oriented policies which were stimulated in many developing countries. Free market was encouraged and was supported by the export approach. Promoting exports was seen as the panacea for full recovery and correction of external sector imbalances. This line of argument is still valid as recent studies indicate (Zahler, (2011), Wang and Whalley (2011); Nguyen and Servén (2011). 


\section{International Journal of Business Management and Economic Review}

Vol. 2, No. 04; 2019

ISSN: 2581-4664

Promoting exports and achieving export expansion is believed to be beneficial to a country for several reasons. These are (i) generation of greater capacity utilization ; (ii) taking advantage of economies of scale; (iii) bringing about technological progress; (iv) creating employment and increasing labour productivity; (v) improving allocation of resources; (vi) increasing the country's external earnings and attract foreign investment and (vii) increase total factor productivity and consequently the well-being of the country.

The export-led growth hypothesis has been tested empirically by many researchers, including Belassa (1978, 1985; Darrat (1987), Michaelly (1977). All studies report appositive association between export growth and output growth. Recent studies on the same strand of literature include Amokom (2012); Kilavuz and Topeu; Torayeh, (2011) and Teboho et. al. (2016).

Country-specific and regional studies include Eichengreen (2011) Fosu (2007); Herzer et.al. (2006); Kimberley et. al. (2011); Salvatore and Hatcher (1991); Brown and Kee (2011); Yusuf (2010); Ram, (1985, 1987); Oxley, (1993); Thorton, (1996); Ngoc et.al, (2003). Tanzania case studies include Kahyarara, (2013); who, as mentioned earlier, mainly used manufactured exports, Rwakalaza,(2015); who analyzed agricultural exports and Mohamed et.al. (2012), who use disaggregated exports into goods and services. The study by Opoka (2014) treated exports in aggregate terms in a study of East African Community countries where Tanzania is a member.

Table 2 .summarizes selected empirical studies with a bit of details on the model used, variables included and the findings.

Table 2: Summary of related empirical studies on Export-Led Growth Hypothesis

\begin{tabular}{|c|c|c|c|c|c|c|c|}
\hline \multirow[t]{2}{*}{ Study } & \multirow{2}{*}{$\begin{array}{l}\text { Period/ } \\
\text { Coverag } \\
\text { e }\end{array}$} & \multicolumn{5}{|c|}{ Methodology } & \multirow[t]{2}{*}{ Conclusions } \\
\hline & & $\begin{array}{l}\text { Data } \\
\text { set }\end{array}$ & $\begin{array}{l}\text { Econo } \\
\text { mic } \\
\text { growth }\end{array}$ & Exports & $\begin{array}{l}\text { Econometr } \\
\text { ic } \\
\text { Technique }\end{array}$ & Other variables & \\
\hline $\begin{array}{l}\text { Al-Yusuf } \\
\text { (1997) }\end{array}$ & $\begin{array}{l}1973- \\
1993 \\
\text { Arab } \\
\text { Gulf } \\
\text { Countri } \\
\text { es }\end{array}$ & $\begin{array}{l}\text { Time } \\
\text { series }\end{array}$ & $\begin{array}{l}\text { Real } \\
\text { GDP } \\
\text { growth }\end{array}$ & $\begin{array}{l}\text { Real } \\
\text { growth } \\
\text { of } \\
\text { exports } \\
\text { and } \\
\text { export } \\
\text { change/o } \\
\text { utput }\end{array}$ & $\begin{array}{l}\text { ADF, } \\
\text { production } \\
\text { function }\end{array}$ & $\begin{array}{l}\text { Labour force } \\
\text { and GDI/GDP }\end{array}$ & $\begin{array}{l}\text { Supports ELGH in } \\
\text { the short } \\
\text { run but no co- } \\
\text { integration }\end{array}$ \\
\hline $\begin{array}{l}\text { Islam } \\
\text { (1996) }\end{array}$ & $\begin{array}{l}1967- \\
1991\end{array}$ & $\begin{array}{l}\text { Time } \\
\text { series }\end{array}$ & $\begin{array}{l}\text { Real } \\
\text { GDP } \\
\text { growth }\end{array}$ & $\begin{array}{l}\text { Export } \\
\text { growth } \\
\text { and } \\
\text { export } \\
\text { change/ } \\
\text { GDP }\end{array}$ & $\begin{array}{l}\text { ADF unit } \\
\text { root test, } \\
\text { Granger } \\
\text { causality } \\
\text { test, error } \\
\text { correction } \\
\text { model }\end{array}$ & $\begin{array}{l}\text { Imports, } \\
\text { government } \\
\text { non-Defense } \\
\text { expenditures, } \\
\text { trade } \\
\text { orientation, } \\
\text { investment, } \\
\text { stability in }\end{array}$ & $\begin{array}{l}\text { Evidence supports } \\
\text { hypothesis } \\
\text { in the short run, but } \\
\text { no co-integration }\end{array}$ \\
\hline
\end{tabular}




\section{International Journal of Business Management and Economic Review}

Vol. 2, No. 04; 2019

ISSN: 2581-4664

\begin{tabular}{|c|c|c|c|c|c|c|c|}
\hline & & & & & & export earnings & \\
\hline $\begin{array}{l}\text { Begun and } \\
\text { Shamshudi } \\
\text { n (1998) }\end{array}$ & $\begin{array}{l}1961- \\
1992 \\
\text { Banglad } \\
\text { esh }\end{array}$ & $\begin{array}{l}\text { Time } \\
\text { series }\end{array}$ & $\begin{array}{l}\text { Real } \\
\text { GDP }\end{array}$ & $\begin{array}{l}\text { Export } \\
\text { growth } \\
\text { and } \\
\text { export } \\
\text { change/o } \\
\text { utput }\end{array}$ & $\begin{array}{l}\text { OLS, } \\
\text { VAR } \\
\text { production } \\
\text { function, } \\
\text { MLE } \\
\text { estimation } \\
\text { and ARCH } \\
\text { model }\end{array}$ & $\begin{array}{l}\text { Labour force, } \\
\text { GDI/GDP, } \\
\text { dummy and } \\
\text { trend }\end{array}$ & $\begin{array}{l}\text { Supports } \\
\text { hypothesis }\end{array}$ \\
\hline $\begin{array}{l}\text { Sengupta } \\
\text { ( 1991) }\end{array}$ & $\begin{array}{l}1967- \\
1986 \\
\text { South } \\
\text { East } \\
\text { Asia } \\
\text { (Republ } \\
\text { ic of } \\
\text { Korea) }\end{array}$ & $\begin{array}{l}\text { Time } \\
\text { series }\end{array}$ & $\begin{array}{l}\text { Real } \\
\text { GDP } \\
\text { growth }\end{array}$ & $\begin{array}{l}\text { Real } \\
\text { export } \\
\text { growth }\end{array}$ & $\begin{array}{l}\text { OLS, } \\
\text { production } \\
\text { function }\end{array}$ & $\begin{array}{ll}\text { Labour } & \text { growth } \\
\text { and } & \text { capital } \\
\text { growth } & \end{array}$ & $\begin{array}{l}\text { Supports export-led } \\
\text { growth hypothesis, } \\
\text { suggests the positive } \\
\text { externality of } \\
\text { exports on growth }\end{array}$ \\
\hline $\begin{array}{l}\text { Torayeh }(20 \\
11)\end{array}$ & Egypt & $\begin{array}{l}\text { Time } \\
\text { series }\end{array}$ & GDP & $\begin{array}{l}\text { Manufac } \\
\text { tured } \\
\text { Exports }\end{array}$ & $\begin{array}{l}\text { Cointegrat } \\
\text { ion and } \\
\text { Error } \\
\text { Corredtion }\end{array}$ & none & Supports hypothesis \\
\hline $\begin{array}{l}\text { Mohamed } \\
\text { et.al. } \\
\text { (2012) }\end{array}$ & $\begin{array}{l}\text { 1970-89 } \\
\text { Tanzani } \\
\text { a }\end{array}$ & $\begin{array}{l}\text { Time } \\
\text { series }\end{array}$ & GDP & $\begin{array}{l}\text { Goods } \\
\text { export }\end{array}$ & OLS & Services export & $\begin{array}{l}\text { Supports hypothesis } \\
\text { for services } \\
\text { exports but not goods } \\
\text { export, } \\
\text { finds co-integration }\end{array}$ \\
\hline $\begin{array}{l}\text { Kahyarara } \\
(2013)\end{array}$ & $\begin{array}{l}\text { Tanzani } \\
\text { a }\end{array}$ & $\begin{array}{l}\text { Time } \\
\text { series }\end{array}$ & $\begin{array}{l}\text { Manuf } \\
\text { actured } \\
\text { Value } \\
\text { added }\end{array}$ & $\begin{array}{l}\text { Manufac } \\
\text { tured } \\
\text { goods }\end{array}$ & $\begin{array}{l}\text { OLS, } \\
\text { ADF, co- } \\
\text { integration }\end{array}$ & $\begin{array}{l}\text { Capital, Labour, } \\
\text { Human capital }\end{array}$ & $\begin{array}{l}\text { Supports export -led } \\
\text { growth hypothesis }\end{array}$ \\
\hline $\begin{array}{l}\text { Opoka } \\
(2014)\end{array}$ & $\begin{array}{l}\text { East } \\
\text { Africa } \\
\text { (Tanzan } \\
\text { ia, } \\
\text { Kenya, } \\
\text { Uganda, } \\
\text { Rwanda } \\
\text { Burundi } \\
\end{array}$ & $\begin{array}{l}\text { Time } \\
\text { series }\end{array}$ & GDP & Exports & $\begin{array}{l}\text { OLS, Co- } \\
\text { integration }\end{array}$ & Terms of Trade & Supports hypothesis \\
\hline
\end{tabular}




\section{International Journal of Business Management and Economic Review}

Vol. 2, No. 04; 2019

ISSN: $2581-4664$

\begin{tabular}{|l|l|l|l|l|l|l|l|}
\hline $\begin{array}{l}\text { Rwekazala } \\
(2015)\end{array}$ & $\begin{array}{l}\text { Tanzani } \\
\text { a }\end{array}$ & $\begin{array}{l}\text { Time } \\
\text { series }\end{array}$ & GDP & $\begin{array}{l}\text { Agricult } \\
\text { ural } \\
\text { exports }\end{array}$ & $\begin{array}{l}\text { OLS, co- } \\
\text { integration }\end{array}$ & investment & Supports hypothesis \\
\hline $\begin{array}{l}\text { Teboho et. } \\
\text { al. (2016) }\end{array}$ & SADC & $\begin{array}{l}\text { Panel } \\
\text { data }\end{array}$ & GDP & Exports & $\begin{array}{l}\text { Cointegrat } \\
\text { ion }\end{array}$ & none & Supports hypothesis \\
\hline
\end{tabular}

Source : Medina Smith (2001) and literature survey.

\section{METHODOLOGY}

\section{Data}

Series for GDP, Y investment K, imports M, labour L and exports X were taken from National Accounts of Tanzania, published by the National Bureau of Statistics.

Table 3: Temporal Properties of the Variables

\begin{tabular}{|l|l|l|l|l|l|}
\hline Variable & Mean & $\begin{array}{l}\text { Standard } \\
\text { Deviation }\end{array}$ & Variance & Skewness & Kurtosis \\
\hline GDP & 181.796 & 849.732 & 722044.3 & 4.9 & 25.024 \\
\hline Exports & 3.589 & 3.112 & 9.687 & 0.834 & 2.232 \\
\hline Imports & 5.475 & 4.160 & 19.617 & 0.829 & 2.105 \\
\hline Labour Force & 17.518 & 4.160 & 17.309 & 0.335 & 1.962 \\
\hline Investment & 23.845 & 5.578 & 31.114 & 0.036 & 1.773 \\
\hline
\end{tabular}

\section{The model}

Following Kimberly et. al. (2011) the empirical model begins with the Cobb-Douglas production function $\mathrm{Y}=\mathrm{AtKt} \square \mathrm{Lt} \beta$

\section{(1)}

Where Yt represents aggregate output at time $\mathrm{t}$, At is the level of factor productivity, Kt is the level of capital stock and $\mathrm{L}$ is the stock of labour. The shares of capital and labour of income are represented by $\square$ and $B$, respectively. We then augment the production function by including exports as a third input which makes total factor productivity become captured. It is assumed that total factor productivity is determined by exports and imports and other exogenous factors.

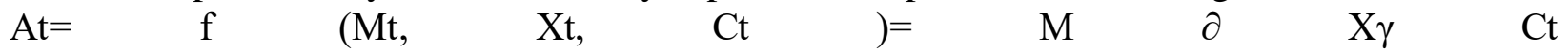

(2).

Combining (2) and (1) we arrive at

$\mathrm{Yt}$

$=\mathrm{CK} \square \mathrm{L} \beta \mathrm{M} \partial \mathrm{X} \gamma$

(3)

Where $\square, \beta, \partial$ and $\gamma$ are elasticities of production with respect to $\mathrm{K}, \mathrm{L}, \mathrm{M}$ and $\mathrm{X}$ respectively.

To be able to estimate equation (3) we take natural logs and express it econometrically as in equation (4).

$\mathrm{LY}=a+\square \mathrm{LK}+\beta \mathrm{LL}+\partial \mathrm{LM}+\gamma \mathrm{LX}+\mathrm{vt}$

Where L stands for Log; $a$ is a constant parameter; the coefficients are constant elasticities and $v$ is an error term that captures the influence of other factors.

Literature shows that there is need to separate the economic influence of exports on output from 


\section{International Journal of Business Management and Economic Review}

Vol. 2, No. 04; 2019

ISSN: 2581-4664

the influence incorporated into the growth accounting relationship (Belassa, 1978, 1985; Darrat1987; Michaelly, 1977). Following Kimberley et. al. (2011) this can be addressed by use of output net of exports which we do in equation (5)

$\mathrm{LNYt}=a+\square \mathrm{LKt}+\beta \mathrm{LLt}+\partial \mathrm{LMt}+\gamma \mathrm{LXt}+\mathrm{vt}$

Where,

LNYt represents growth in GDP. The signs of the coefficients $\alpha, \beta, \partial$ and $\gamma$ are expected to be positive.

\section{Econometric Methodology}

We estimate the short-run dynamics by means of Granger-causality test from an error correction model. The purpose is to find out whether exports leads growth, growth leads exports, both or neither hold true for Tanzania. This is specified in equations (6) and (7).

\section{$\Delta \mathrm{LNY}=c 0+[\square \mathrm{i} \Delta \mathrm{LKt}-1+\beta \Delta \mathrm{LLt}-1+\partial \Delta \mathrm{LMt}+\gamma \Delta \mathrm{LXt}+\Delta \mathrm{LNYt}-1]+\Phi \mathrm{ECTt}+\mathrm{ut}$}

(6)

\section{$\Delta \mathrm{LX}=c 0+[\square \mathrm{i} \Delta \mathrm{LKt}+\beta \Delta \mathrm{LLt}+\partial \Delta \mathrm{LMt}+\gamma \Delta \mathrm{LXt}-1+\Delta \mathrm{LNYt}-1]+\Phi \mathrm{ECT}+\mathrm{et}$}

(7)

where $\Delta$ is the difference operator and ECT is the error correction term which represents the lagged error from the co-integration equation.

Before model estimation, we avoid spurious regression by testing for unit root. To this end, we first establish the variables order of integration. In brief, a variable is integrated of order ' $d$ ' written (d) if it required differencing d times before it achieves stationary. To test for the integration properties of the variables concerned we employ standard unit root tests, the augmented Dickey-Fuller (ADF) and the Phillips-Peron (PP) tests.

The results of these tests for each variable are provided in Table 4 and it can be seen that the ADF and PP tests suggest non-stationary variables when expressed in levels. These tests indicate that the variables under consideration are integrated of order I.

Table 4 : ADF and PP Unit Root Tests

\begin{tabular}{|l|l|l|l|l|}
\hline Variables & Levels & First Differences \\
\hline & ADF & PP & ADF & PP \\
\hline LNY & -2.217 & -1.970 & $-3.368^{* *}$ & $-3.278^{* *}$ \\
\hline LK & -2.246 & -1.908 & $-3.548^{* *}$ & $-3.508^{* *}$ \\
\hline LL & -1.423 & -0.206 & -1.111 & -1.231 \\
\hline LM & -2.214 & -1.813 & $-3.457^{* *}$ & $-3.424^{* *}$ \\
\hline LX & -2.505 & -1.853 & -2.170 & -2.189 \\
\hline $\begin{array}{l}\text { Critical values } \\
\text { at } 10 \% \text { level }\end{array}$ & & & & \\
\hline
\end{tabular}

Note: $* *$ denotes significance at 5 percent level.

The finding that the variables contain a unit root raises the possibility of a long run relationship 


\section{International Journal of Business Management and Economic Review}

Vol. 2, No. 04; 2019

ISSN: 2581-4664

among them. We therefore proceed to evaluate their multivariate temporal property using cointegration analysis. The variables are said to be co-integrated or share a long run equilibrium if their linear combination, although they are individually non-stationary, is stationary. What is implied by this is that the co-integrated variables will not drift further away from each other arbitrarily (Johansen, 1988; Juselius, 1990).

The Johansen (1988) and Johansen and Juselius (1990) approach is followed. The approach is essentially a vector out regression based test, treating all variables as potentially endogenous. The test is also capable of identifying multiple co-integrating vectors. The tests statistics have been developed by Johansen and Juselius (1990) to test for the number of co-integrating vectors, the trace and the number of maximum Eigen value statistics. In the procedure, the lag length of the tests is selected such that the residuals are serially uncorrelated. The results of these tests are reported in Table 5.

The results presented in Table 5 indicate the presence of a unique co-integrating vector, for the basic model. The null hypothesis of no co-integration $(\mathrm{r}=0)$ is rejected at the 5 percent significance level while the null hypothesis of almost one co integrating vector cannot be rejected. When we add import ratios and population growth, the trace and maximum Eigen value statistics at the 5 percent significance level indicted the presence of a unique counteracting vector, among the two sets of variables.

\section{Table 5: Johansen Co-integration test results}

\begin{tabular}{|l|l|l|l|l|}
\hline Trace test & $\begin{array}{l}\text { Null } \\
\text { hypothesis }\end{array}$ & $\begin{array}{l}\text { Alternative } \\
\text { Hypothesis }\end{array}$ & Test Statistic & $\begin{array}{l}5 \% \\
\text { Value }\end{array} \quad$ Critical \\
\hline & $\mathrm{r}=0$ & $\mathrm{r} \leq 1$ & $55.345^{* *}$ & 40.865 \\
\hline & $\mathrm{r}=1$ & $\mathrm{r} \leq 2$ & 17.608 & 20.132 \\
\hline & $\mathrm{r}=2$ & $\mathrm{r} \leq 3$ & 10.446 & 15.657 \\
\hline & $\mathrm{r}=3$ & $\mathrm{r} \leq 4$ & 3.224 & 5.643 \\
\hline & $\mathrm{r}=4$ & $\mathrm{r} \leq 5$ & 0.345 & 3.231 \\
\hline & & & & \\
\hline $\begin{array}{l}\text { Max Eigen } \\
\text { value test }\end{array}$ & & & & \\
\hline & $\mathrm{r}=0$ & $\mathrm{r}=0$ & & \\
\hline & $\mathrm{r}=1$ & $\mathrm{r}=1$ & $31.073^{* *}$ & 29.456 \\
\hline & $\mathrm{r}=2$ & $\mathrm{r}=2$ & 8.234 & 20.560 \\
\hline & $\mathrm{r}=3$ & $\mathrm{r}=3$ & 4.234 & 8.090 \\
\hline & $\mathrm{r}=4$ & $\mathrm{r}=4$ & 0.325 & 3.802 \\
\hline
\end{tabular}

Note: $* *$ denotes is significance at the 5 percent level.

\section{Estimation Results}

Existence of co-integration among the variables suggests that these variables must be temporally and causally linked in at least on direction. This empirical finding, allows us estimate an error correction model (ECM) to present the causal link among the co-integrated variables. The ECM 


\section{International Journal of Business Management and Economic Review}

Vol. 2, No. 04; 2019

ISSN: 2581-4664

combines variables in first differences and the error correction term to explain the dynamic behavior of all variables of interest.

Table 6: Error Correction Model Results

\begin{tabular}{|l|l|l|l|l|}
\hline $\begin{array}{l}\text { Dependent } \\
\text { Variable }\end{array}$ & $\begin{array}{l}\text { Explanatory } \\
\text { Variable }\end{array}$ & Coefficient & t-Statistic & P-Values \\
\hline$\Delta$ LNY & $\mathbf{\Delta L M}$ & 0.666 & 3.012 & 0.001 \\
\hline & $\mathbf{\Delta L X}$ & 0.264 & 1.896 & 0.003 \\
\hline & $\mathbf{\Delta L L}$ & 0.175 & 1.945 & 0.000 \\
\hline & $\mathbf{\Delta L K}$ & 0.162 & 2.342 & 0.005 \\
\hline & ECT & -0.03 & -3.92 & 0.000 \\
\hline & Constant & 1.432 & & \\
\hline & & Adj. R2 $=0.86$ & & \\
\hline & & D. W. $=1.82$ & & \\
\hline & & F= 54 & & \\
\hline
\end{tabular}

From the Vector Error Correction Estimates, it appears that the change in the value of exports and imports govern the change in the value of the GDP. This implies that production of goods for export will expand the economy. The results of the ECM model suggest a long term relationship between exports and imports on economic growth which is in support of the hypothesis that the export-led growth hypothesis was valid in Tanzania during the period of study.

\section{CONCLUSION}

The study has empirically tested the export-led growth hypothesis (ELGH) for the case of Tanzania. The results suggest that the export growth stance is viable for the country, concurring with earlier findings in Kahyarara (2013) and Rwakazala (2015) who however confined their studies in manufacturing and agricultural exports respectively. Starting the mid 1990s when the import substitution strategy (ISS) was abandoned, the country recovered to a stronger growth after opening up to the rest of the world. Exports provided basis for learning and tax revenues needed for government expenditures for infrastructure, education and technology. In view of the move towards a semi-industrial economy there is need to emphasize export-led manufacturing to ease the foreign exchange constraint, increase job creation and maintain high unemployment.

It is important for Tanzania policy makers to have instruments available to help the country maximize the benefits of openness while minimizing the volatility that might come with it. This will lend support to the fifth phase government commitment towards a semi- industrial economy by the year 2025 .

\section{REFERENCES}

Al-Yusuf, Y. K (1997) Exports and Economic Growth: Some Empirical Evidence from the Arab Gulf Countries" Applied Economics, 29,6

Amakom, U. (2012) "Manufactured Exports in Sub-Saharan African Economies: Econometric 


\section{International Journal of Business Management and Economic Review}

Vol. 2, No. 04; 2019

ISSN: 2581-4664

Tests of the Learning by Exports Hypothesis" American International Journal of Contemporary Research, 2:4

Begum, S. and A.F.M. Shamshudin (1998) "Exports and Economic Growth in Bangladesh" Journal of Development Studies, 31, 1

Belassa, B. (1978) "Exports and Economic Growth: Further Evidence" Journal of Development Economics, 5

Belassa, B. ( 1985) "Exports, Policy Choices, and Economic Growth in Developing Countries After the Oil Shock" Journal of Development Economics, 18.

Brown, C and H.L. Kee (2011), "Developing Countries, New Trade Barriers, and the Global Economic Crisis", in M Haddad, and B Shepherd (eds.), Managing Openness: Trade and Outward-Oriented Growth after the Crisis, World Bank.

Darrat, A. (2000) "Are Exports an Engine of Growth ? Another Look at the Evidence" Applied Economics, 19

Eichengreen, B (2011), "Managing Openness: Lessons from the Crisis for Emerging Markets", in M Haddad, and B Shepherd (eds.), Managing Openness: Trade and Outward-Oriented Growth after the Crisis, World Bank.

Ekanayake, E.M. (1999) "Exports and Economic Growth in Asian Developing Countries: Cointegration and Error Correction Model” Journal of Economic Development, Vol. 24 (2)

Fosu, M. (2007) "Exports and Economic Growth: the African Case" World Development 18 (6)

Granger, C. W. J.(1981). "Some properties of Time Series Data and their use in Econometric Model Specification",. Journal of Econometrics, Annals of Applied Econometrics, 16: 121-30.

Granger, C. W. J. (1986). "Developments in the Study of Co-integrated Economic Variables", Oxford

Bulletin of Economics and Statistics, 48, 3 (August): 213-28.

Hendry, D. F. (1986). "Econometric Modeling with Co-integrated Variables: An overview", Oxford

Henrique, I. and P. Sadorsky (1996). "Export-led growth or growth-driven exports? The Canadian Case", Canadian Journal of Economics, 29, 3 (August): 541-55.

Herzer, D., Nowak-Lehmann, F. and Silverstovs, B. (2006) "Export-led Growth in Chile: Assessing the Role of Export Composition in Productivity Growth". The Developing Economies 44 , no. 3, 306-28.

Islam, M.N. (1998) "Export Expansion and Economic Growth: Testing for Cointegration and Causality" Applied Economics 30, no. 3, 415-25.

Kahyarara, G. (2013)" Tanzania Manufactured Exports and Growth: A Co-integration Approach" International Journal of Economics and Management Sciences, Vol. 2 No. 12 


\section{International Journal of Business Management and Economic Review}

Vol. 2, No. 04; 2019

ISSN: 2581-4664

Kanaan, O. (2000). "Tanzania's Experience with trade liberalization". Finance and Development, Vol.37 No. 2

Kilavuz, E. and Topeu, B. A. (2012) "Exports and Economic Growth in the Case of the Manufacturing Industry: Panel Data Analysis of Developing Countries "International Journal of Economics and Financial Issues, Vol. 2, No. 2

Kimberley, W., T. Lorde, and B. Francis (2011) "Export-Led Growth: A Case Study of Mexico" International Journal of Business, Humanities and Technology, Vol. 1 No. 1

Kokko, A. (1997) "Managing the Transition to Free Trade: Vietnamese Trade Policy for the 21 st Century. Swedish International Development Cooperation Agency

Kokko, A. (2006) "Export -Led Growth in East Asia: Lessons for Europe's transition economies" Emerging Multiplicity

Krueger, A. O. (1978). Foreign Trade Regimes and Economic Development: Liberalization Attempts and Consequences. Cambridge, MA: Ballinger.

Medina-Smith, E. (2001) "Is the Export-Led Growth Hypothesis Valid for Developing Countries? A Case Study of Costa Rica" UN, New York and Geneva

Michaely, M. (1977) "Exports and Growth: An Empirical Investigation" Journal of Development Economics, 4.

Mohamed, M. R., Chung-Yee Liew, and S.S. Mzee (2012) "Export Trade and Economic Growth in Tanzania: A Disaggregated Approach" Journal of Economics and Sustainable Development, Vo. 3, no.12

Monna-Haddad, M, J Lim, L Munro, C Saborowski, and B Shepherd (2011a), "Volatility, Export Diversification, and Policy", in M Haddad, and B Shepherd (eds.), Managing Openness: Trade and Outward-Oriented Growth after the Crisis, World Bank.

Monna-Haddad, M, and B Shepherd (eds.) (2011b), "Managing Openness: From Crisis to Export-Led Growth", in M Haddad, and B Shepherd (eds.), Managing Openness: Trade and Outward-Oriented Growth after the Crisis, World Bank.

Ngoc, P. M. , N,. T. Phuong Anh and P.T. Nga (2003) "Exports and Long-Run Growth in Vietnam. 1976-2001. ASEAN Economic Bulletin, 20, 1-25.

Nguyen, H, and L Servén (2011a), "Global Imbalances: Past and Future", In M Haddad, and B Shepherd (eds.), Managing Openness: Trade and Outward-Oriented Growth after the Crisis, World Bank.

Nguyen, H, and L Servén (2011b) "Changing Dynamics in Global Trade", in M Haddad and B Shepherd (eds.) Managing Openness: Trade and Outward-Oriented Growth after the Crisis, World Bank.

Opoka, J. (2014 )"Export Led Growth Hypothesis : Panel Co-integration Evidence From East Africa" unpublished thesis 


\section{International Journal of Business Management and Economic Review}

Vol. 2, No. 04; 2019

ISSN: $2581-4664$

Oxley, L. (1993) "Co-integration, causality and export-led growth in Portugal, 1865-1985. Eco

Pavcnik, N (2002), "Trade Liberalization, Exit, and Productivity Improvement: Evidence from Chilean Plants", Review of Economic Studies, 69(1):245-276.

Rodriguez, Mauro (2010). "Import Substitution and Economic Growth" Journal of Monetary Economics, Vol. 57, No. 2.

Rwakazala, R. (2015). Export-led growth Hypothesis: Evidence from Agricultural Exports in Tanzania. African Journal of Economic Review, Vol.III Issue 2.

Ram, R. (1985). Exports and economic Growth: Some Additional Evidence. Economic Development and Cultural Change, 33, 415-425.

Ram, R., (1987),"Exports and Economic growth in Developing Countries: Evidence from Time Series and Cross-Section Data", Economic Development and Cultural Change", vol.36, pp.5172.

Salvatore, D., and T. Hatcher, (1991),"Inward Oriented and Outward Oriented Trade Strategies", The Journal of Development Studies, vol. 27, pp. 7-25.

Sharma, A., and T. Panagiotidis (2005) "An Analysis of Exports and Growth in India: Cointegration and Causality Evidence (1971-2001)". Review of Development Economics, 9, 232248.

Sengupta, J. K. (1991)"Rapid Growth in NCIs Asia: Tests of New Growth Theory in Korea" Kyklos, 44,4

Teboho, U. M., C. S.Mmamotsho, and J. H. Eita (2016) “ Manufactured Exports and Economic Growth in Southern African Development Community (SADC) Region: A Panel Cointegration Approach" Economica, Vol. 12No. 5

Thorton, J. (1996). Co-integration, Causality and export-led growth in Mexico: 1895-1992. Economics Letters, 50, 413-416.

Torayeh, N. M. (2011) "Manufactured Exports and Economic Growth in Egypt: Cointegration and Causality Analysis" Applied Econometrics and International Development, Vol. 11-1

Tyler, W. G., (1981),"Growth and Export Expansion in Developing Countries: Some Empirical Evidence", Journal of Development Economics, vol. 9, pp. 121-130.

Wang J, and J. Whilley (2011),"China's Trade and Investment with the South Pre- and PostCrisis", in M Haddad and B Shepherd (eds.), Managing Openness: Trade and Outward-Oriented Growth after the Crisis. World Bank.

Yao, Y. (2011).China's Export-led growth model. http://www.eastasianforum.org/2011/02/27/ 
International Journal of Business Management and Economic Review

Vol. 2, No. 04; 2019

ISSN: 2581-4664

Yusuf, S. (2010) "The Past and Future of Export-led Growth". http://blogs.worldbank.org/growth/past-and-future-export-le-growth Bulletin of Economics and Statistics, 48, 3 (August): 201-12.

Zahler, R (2011), "The International Crisis and Development Strategies: The Case of Chile", in M Haddad, and B Shepherd (eds.), Managing Openness: Trade and Outward-Oriented Growth after the Crisis, World Bank. 